\title{
DE
} DE GRUYTER OPEN

\section{PATHOPHYSIOLOGICAL RESPONSE TO EXPERIMENTAL ORAL OVERDOSE OF DIFFERENT FORMS OF SELENIUM IN LAMBS*}

\author{
Raquel Lopez-Arellano ${ }^{1}$, J. Efren Ramirez-Bribiesca ${ }^{2 \star}$, Jaime Jaimes-Miranda ${ }^{1}$, Jorge L. Tortora- \\ -Perez ${ }^{1}$, Alma L. Revilla-Vazquez ${ }^{1}$, Gabriela Rodriguez-Patiño ${ }^{1}$, Martin F. Montaño-Gomez ${ }^{3}$ \\ ${ }^{1}$ Facultad de Estudios Superiores Cuautitlán, Universidad Nacional Autónoma de México, \\ Carretera Cuautitlán-Teoloyucan Km. 2.5, 54714 San Sebastián Xhala, Cuautitlán Izcalli, \\ Estado de México, México \\ ${ }^{2}$ Colegio de Postgraduados, Ganaderia, Carretera México-Texcoco Km. 36.5, 56230 Montecillo, \\ Estado de México, México \\ ${ }^{3}$ Instituto de Investigaciones en Ciencias Veterinarias, Universidad Autónoma de Baja California, \\ Carretera San Felipe Fracc. Campestre Km. 3.5, Mexicali, Baja California, México \\ •Corresponding author: efrenrb@colpos.mx
}

\begin{abstract}
Twelve male lambs $(30.5 \pm 2.1 \mathrm{~kg})$ with cannulas in the rumen were divided into three groups to evaluate the accidental toxicity of selenium (Se) via digestive tract. The first group received intraruminal bolus without a Se source; the second group received intraruminal bolus with sodium selenite ( $\mathrm{SS}: \mathrm{Na}_{2} \mathrm{SeO}_{3}$ ); the third group received intraruminal bolus with barium selenate (BS: $\mathrm{BaSeO}_{4}$ ). The ruminal boluses were immediately degraded by a manufacturing defect, releasing an amount of $366 \mathrm{mg}$ Se via rumen. All lambs had tachypnea (80 cycles per minute), a metallic smell in the oral cavity and laminitis foot. Analyses of necropsy and histopathology showed frequencies of lesions in the myocardium and skeletal muscle, lesions in the myocardium were more common in lambs intoxicated with SS or BS than the control group $(\mathrm{P}<0.05)$; the tissues were swollen and there were hyaline fibres (Zenker degeneration), as well as fragments and proliferation of the nuclei with necrosis. Se concentration in lambs intoxicated with SS and BS were: myocardium: 0.389 and 0.332 ; skeletal muscle: 0.583 and 0.492 ; and kidney: 2.871 and $2.841 \mu \mathrm{g} / \mathrm{g}$ fresh tissue, respectively. The Se concentration in blood increased over 2.5 times in the intoxicated lambs with both sources of $\mathrm{Se}(0.14 \mathrm{vs} .0 .36 \mu \mathrm{g} / \mathrm{mL})$ from baseline to the 22 days of sampling. There was a lower correlation $(r=0.46)$ in SS intoxication group than the control and BS group $(r \geq 0.93)$. As a conclusion, high dosages of $366 \mathrm{mg}$ Se or $12 \mathrm{mg} \mathrm{Se} / \mathrm{kg} \mathrm{BW}$ in an accidental dosage did not cause a severe mortality but all lambs immediately showed reduced feed intake, metallic smell exhalation and depression.
\end{abstract}

Key words: barium selenate, glutathione peroxidase, sodium selenite, toxicity

*Financial support was provided by "Fideicomiso Revocable de Administración e Inversión No.167304, 2013, Colegio de Postgraduados, México". 
Selenium (Se) is the key structural component of selenoproteins like glutathione peroxidase and iodothyronine deiodinase which catalyses the conversion of thyroxine into triiodothyronine (Behne and Kyriakopoulos, 2001). Dietary requirement of Se for sheep was $0.1-0.2 \mathrm{mg} \mathrm{Se} / \mathrm{kg} \mathrm{DM}$ and it was established based on glutathione peroxidase (GSH-Px) activity and protection against Se-dependent diseases. Specifically, the requirement for growing lambs has been revised to $0.2-0.3 \mathrm{mg} \mathrm{Se} / \mathrm{kg} \mathrm{DM}$ with average daily gains ranging 200-350 g (NRC, 2007). Se has a narrow margin of safety, the toxicity appears in chronic or acute form by an excessive dietary intake or supplementation errors (Davis et al., 2013). The maximum tolerable level increased from 2.0 (NRC, 1983) to $5.0 \mathrm{mg} \mathrm{kg} \mathrm{DM}$ (NRC, 2007), this value was established considering the health of the animal. The mechanism of toxicity causes oxidation and reduction in the organism by inhibiting the enzymatic activity. Gutierrez et al. (2005) mentions that the Se bolus of slow release has no negative effects on the health of animals and bolus duration depends on the concentration of Se and matrix of vehicles when manufactured. Inorganic Se sources commonly used in commercial products are selenite or selenate of sodium and barium selenate (FDA, 2004). The effectiveness of sodium selenite and selenate is similar, but the selenate causes less toxicity and this source is less irritating with better availability (Judson, 1991). Injected barium selenate (BS) has slow availability compared with sodium selenite (SS) and is rapidly absorbed when injected (Kuttler et al., 1961). However, the selenate is used less frequently because it is easily reduced and can form insoluble compounds with other metals.

Current research on Se supplements is looking for safe strategies to prevent Se toxicity and for these supplements to be easily administered, inexpensive and effective. One possibility is the use of controlled bolus intraruminal Se and the ensuring of a gradual release in the rumen by a definite time release. Carrageenans are a variety of room temperature stable gels, firmly adhering to the mucous membranes, which can release various mixed substances (Gurvan et al., 2003). This study evaluated an integral vehicle carrageenan bolus containing SS and BS. Degradation and the effects of the amount of Se in tissues, GSH-Px activity and signs of toxicity in lambs caused by a rapid degradation are considered accidental. The design on the stability of the bolus was not adequate and an exaggerated dose of Se was immediately released into the rumen, causing accidental toxicity in lambs, which forced the study to focus on assessing the physiological response to Se toxicity through the digestive tract.

\section{Material and methods}

\section{Animals}

The trial was conducted using twelve crossbred (Suffolk $\times$ Hampshire) male lambs $(30.5 \pm 2.1 \mathrm{~kg}, 11$ months of age) with rumen cannulas. They were randomly divided into three groups to evaluate the accidental poisoning of lambs with Se from a rumen bolus. Surgeries were performed two months prior to the start of the experi- 
ment. Lambs were housed in an indoor slotted-floor metabolism unit in the Postgraduate College, Mexico. The lambs were placed into metabolic cages $(0.62 \times 0.80 \mathrm{~m})$ 14 days before the initiation of the trial. Prior to the trial, lambs were vaccinated for clostridia diseases (Ultrabac $8 \AA$, SmithKline Beecham) and treated for internal and external parasites (Ivomec Plus ${ }^{\circledR}$ Merck, Rahway, NJ). The treatment of the animals during the surgery and experiment were in accordance with the guidelines of the Mexican Committee of Postgraduate College, Mexico. Composition of the diet is shown in Table 1 and based on tabular values (NRC, 2007) for individual feed ingredients, the diets contained (DM basis) $17 \%$ CP. Dry matter intake and drinking water were available ad libitum, and all lambs were fed approximately with $1080 \mathrm{~g}$ of basal diet, divided into two at 0800 and $1600 \mathrm{~h}$ daily.

Table 1. Composition of basic experimental diet offered to lambs

\begin{tabular}{|c|c|}
\hline Ingredients (DM) & $(\mathrm{g} / 100 \mathrm{~g})$ \\
\hline Corn break & 50.0 \\
\hline Alfalfa hay & 33.0 \\
\hline Soybean meal & 15.0 \\
\hline Limestone/Ca orthophosphate ${ }^{\mathrm{a}}$ & 1.6 \\
\hline Trace mineral salt ${ }^{\mathrm{b}}$ & 0.4 \\
\hline \multicolumn{2}{|l|}{ Nutritional composition (MS) ${ }^{\mathrm{c}}$ : } \\
\hline protein & 17.1 \\
\hline $\mathrm{NDF}$ & 31.9 \\
\hline $\mathrm{ADF}$ & 15.1 \\
\hline ash & 6.3 \\
\hline $\mathrm{Se}(\mu \mathrm{g} / \mathrm{g})$ & 0.23 \\
\hline
\end{tabular}

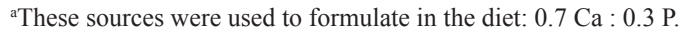

${ }^{\text {b}}$ Trace mineral salt contained the following: $\mathrm{CoSO}_{4} 0.68 \mathrm{~g} / \mathrm{kg}, \mathrm{CuSO}_{4} 1.04 \mathrm{~g} / \mathrm{kg}, \mathrm{FeSO}_{4} 3.57 \%, \mathrm{ZnO} 1.24 \mathrm{~g} /$ $\mathrm{kg}, \mathrm{MnSO}_{4} 1.07 \mathrm{~g} / \mathrm{kg}, \mathrm{KI} 0.052 \mathrm{~g} / \mathrm{kg}, \mathrm{NaCl} 92.96 \mathrm{~g} / \mathrm{kg}$.

${ }^{\mathrm{c}}$ Values obtained from laboratory analysis.

\section{Animal distribution, composition of intraruminal boluses and accidental in- duction of digestive selenosis}

Three groups of animals with four replications each were distributed randomly. The first group received intraruminal bolus without Se source. The second group received intraruminal bolus with $\mathrm{SS}: \mathrm{Na}_{2} \mathrm{SeO}_{3}$. The third group received intraruminal bolus with $\mathrm{BS}: \mathrm{BaSeO}_{4}$. Intraruminal boluses were prepared with and without $\mathrm{Se}$ in the laboratory of Pharmacy FES-C UNAM. The intraruminal boluses were $10 \mathrm{~g}, 2$ $\mathrm{cm}$ long and of 1.8 density, containing $366 \mathrm{mg}$ Se as SS (45\% Se) or BS (27.6\% Se), plus iron, $\mathrm{Mg}$ stearate, methocel and carrageenan to form the matrix of the bolus. These were wrapped with a mesh of $1 \mathrm{~mm}$ diameter, were attached with $60 \mathrm{~cm}$ long string and introduced directly into the rumen through the ruminal cannula, in order to assess the daily degradability of bolus calculating a release of $2 \mathrm{mg} \mathrm{Se} /$ day, but accidentally the bolus was degraded in less than $24 \mathrm{~h}$, predisposing lambs to acute 
exposure of Se via digestion. This problem was immediately notified to The Committee on Ethics and Animal Welfare of Postgraduate College, Mexico, approving the evaluation of trace mineral balance and response to physiological variables during Se exposure.

\section{Sampling}

After administering Se intraruminal bolus, blood samples were collected directly from the jugular vein into tubes containing anticoagulant (Vacutainer procedure) to measure the concentration of Se and GSH-Px activity. Sampling groups were distributed into 1-4, 7-10, 13-16 and 19-22 days post-dosing. Means of each group were obtained from 4 continuous days of sampling. One lamb died immediately ( 2 days), others were euthanized 22 days after starting the experiment, using xilazine and auxiliary exsanguination. Gross lesions found at necropsy were noted. Samples of myocardium and skeletal muscle were taken, fixed in $10 \%$ neutral buffered formaldehyde and processed for histological studies with $5 \mu \mathrm{m}$ sections stained with hematoxylin-eosin. Simultaneously, other samples of myocardium, liver, skeletal muscle, lung and kidney tissue were stored in plastic bags and frozen at $-20^{\circ} \mathrm{C}$ for the analysis of Se.

\section{Laboratory analysis}

Histopatological lesion rates (\%) of myocardium and skeletal muscle were scored for light microscopy evaluation as follows: No injuries $=0$, little bit $=20$, little $=40$, medium $=60$, high $=80$ and very high $=100 \%$; where multiple samples of a particular tissue were examined.

\section{GSH-Px activity and Se concentration}

Samples were analysed in the laboratory of chemistry FES-C, UNAM, Mexico. The GSH-Px was evaluated by the technique modified by Paglia and Valentine (1967) and Se was analysed in dry matter of feed sample and fresh tissues by atomic absorption spectrophotometry with hydride generation after an acid digestion by microwave. Approximately $1 \mathrm{~g}$ of sample, $10 \mathrm{~mL}$ of demineralized $\mathrm{H}_{2} \mathrm{O}$ (Millipore, USA), $5 \mathrm{~mL}$ of nitric acid $\left(\mathrm{HNO}_{3}\right)$ and $2 \mathrm{~mL}$ of hydrogen peroxide $\left(\mathrm{H}_{2} \mathrm{O}_{2}\right)$ (J.T. Baker, Mexico) were placed for $10 \mathrm{~min}$. in a Teflon container and digested using a microwave oven (MAR 5, CEM, Corporation Falcon USA). The containers were cooled to room temperature; the contents were placed in $50 \mathrm{~mL}$ volumetric flask (each container was rinsed three times with $\mathrm{HCl} 7 \mathrm{M}$ ), they were taken to the mark and were phosphorylated with $\mathrm{HCl} 7 \mathrm{M}$. Later, the samples were moved to labelled polyethylene containers and the quantification of the total Se was determined from a calibration curve using Se standard, High-Purity, $1000 \pm 3 \mu \mathrm{g} / \mathrm{ml}$ in $2 \%$ of nitric acid (99.99 purity; Scientific Company Se Powder) (Abd Elghany et al., 2007).

\section{Statistical analyses}

The lambs were divided into 3 treatments with 4 replicates using a completely randomized design. Se concentration in different fresh tissues of lambs by treatments was analysed with GLM procedure. Data of blood Se and GSH-Px activity were 
analysed by Mixed model procedure with treatment as the fixed effect and all replications in time (day 0, 7, 14 and 21) were treated as random effect; when interactions with time were significant, treatment means were compared at each time point. The Pearson correlation between Se concentration and activity of GSH-Px in blood tissue for each treatment was performed and differences between treatment means were analysed with Tukey rank test (SAS Institute, 2007). Mann-Whitney U test was used for comparing the histopatological lesion rates $(\%)$ of the myocardium and skeletal muscle establishing the relationship between the different groups.

\section{Results}

\section{Clinical signs and necropsy findings in lambs exposed to Se excess}

Lambs from the supplemental groups demonstrated clinical signs of intoxication. A day after dosing, all lambs suppressed feed intake by $33.5 \%$; by $50 \%$ on day 10 ; and by $66.5 \%$ on day 21 . All animals intoxicated with Se sources had tachypnea ( 80 cycles per minute), a metallic smell in the oral cavity, laminitis foot. Only one lamb died after the 2nd day of dosing by SS; this animal showed clinical signs of hyperventilation, and a fraction of disintegrated intraruminal bolus remained in the ventral region of the rumen, causing an evident necrotizing effect on the reticulum-ruminal mucosa (Figure 1), there was coagulation necrosis from the epithelial surface to the sub mucosa and part of the muscle. Necropsy also showed pericarditis, dropsy, jaundice, cardiac muscle flaccidity and in the contents of the gallbladder there was present metallic sheen (Figure 1). Histopathology showed lung hyperemia, edema and severe bleeding; there was also a distortion in the structure of the alveoli. The liver showed slight hyperemia, polyploidy and proliferation of bile canaliculi with multifocal coagulation necrosis. The kidneys presented cortico-medullary hyperemia and hemorrhage, the glomeruli were hyperemic and swollen, invading the capsule of Bowman. The proximal and distal convoluted tubules had a severe coagulation necrosis, which contrasted with the headers and loops of Henle.

Analyses of necropsy and histopathology performed on all lambs at 22 days of sacrifice, showing frequencies of lesions in the myocardium and skeletal muscle, were quantified in Table 2. The lesions in both tissues were swollen and there were hyaline fibres (Zenker degeneration), fragments, proliferation of nuclei with necrosis and degenerate structures. Additionally, cells showed infiltration of mononuclear macrophage. The histological lesions in skeletal muscle were most evident with the $\mathrm{SB}$ and SS than the control group $(\mathrm{P}<0.05)$.

\section{Se concentration in tissues}

Administration of the Se bolus resulted in greater $(P<0.05)$ tissue Se accumulation compared with non-Se bolused lambs. Se contents of the tissues were significantly higher than normal by 5-, 1.6-, 5.7- and 4.1-fold in the myocardium, skeletal muscle, lung and kidney, respectively. Furthermore, there also were differences in tissue Se accumulation between treatments among SS-bolused and BS-bolused 
lambs. An accumulation of Se into the all tissues analysed was expected in all lambs intoxicated.
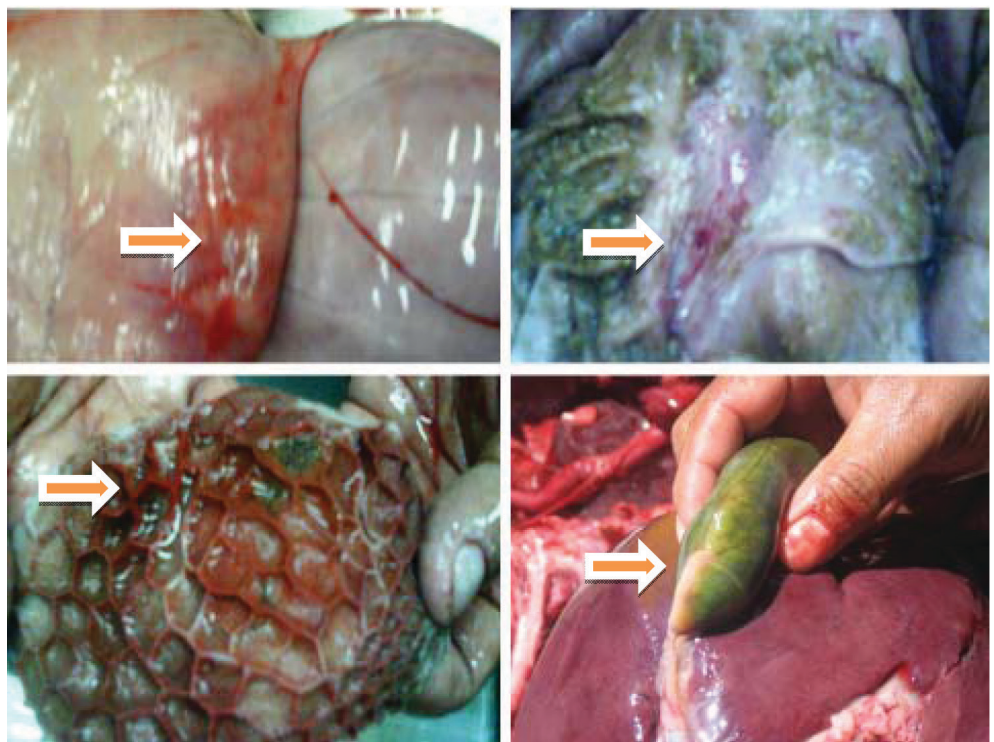

Figure 1. Bleeding in the external and internal mucosa of rumen-reticulum by the rapid degradation of Se bolus and gallbladder brilliance in the necropsy of a lamb intoxicated with sodium selenite

Table 2. Histopatological lesion rates (\%) in tissues of lambs without selenium and intoxicated with an oral overdose of sodium selenite and barium selenate

\begin{tabular}{ccc}
\hline Control & Myocardium & Skeletal muscle \\
\hline Repetition 1 & 40 & 20 \\
2 & 20 & 0 \\
3 & 20 & 20 \\
4 & 20 & 0 \\
Mean & $25 \mathrm{a}$ & $10 \mathrm{a}$ \\
Sodium selenite & & \\
Repetition 1 (this lamb died after 2 days) & 80 & 80 \\
2 & 60 & 60 \\
3 & 100 & 40 \\
4 & 40 & 40 \\
Mean & $70 \mathrm{~b}$ & $55 \mathrm{~b}$ \\
Barium selenate & & \\
Repetition 1 & 60 & 100 \\
2 & 60 & 80 \\
3 & 60 & 80 \\
4 & 60 & 80 \\
Mean & $60 \mathrm{~b}$ & $85 \mathrm{~b}$ \\
\hline
\end{tabular}

$\mathrm{a}, \mathrm{b}-$ means with different letter in each column are different $(\mathrm{P}<0.05)$. 

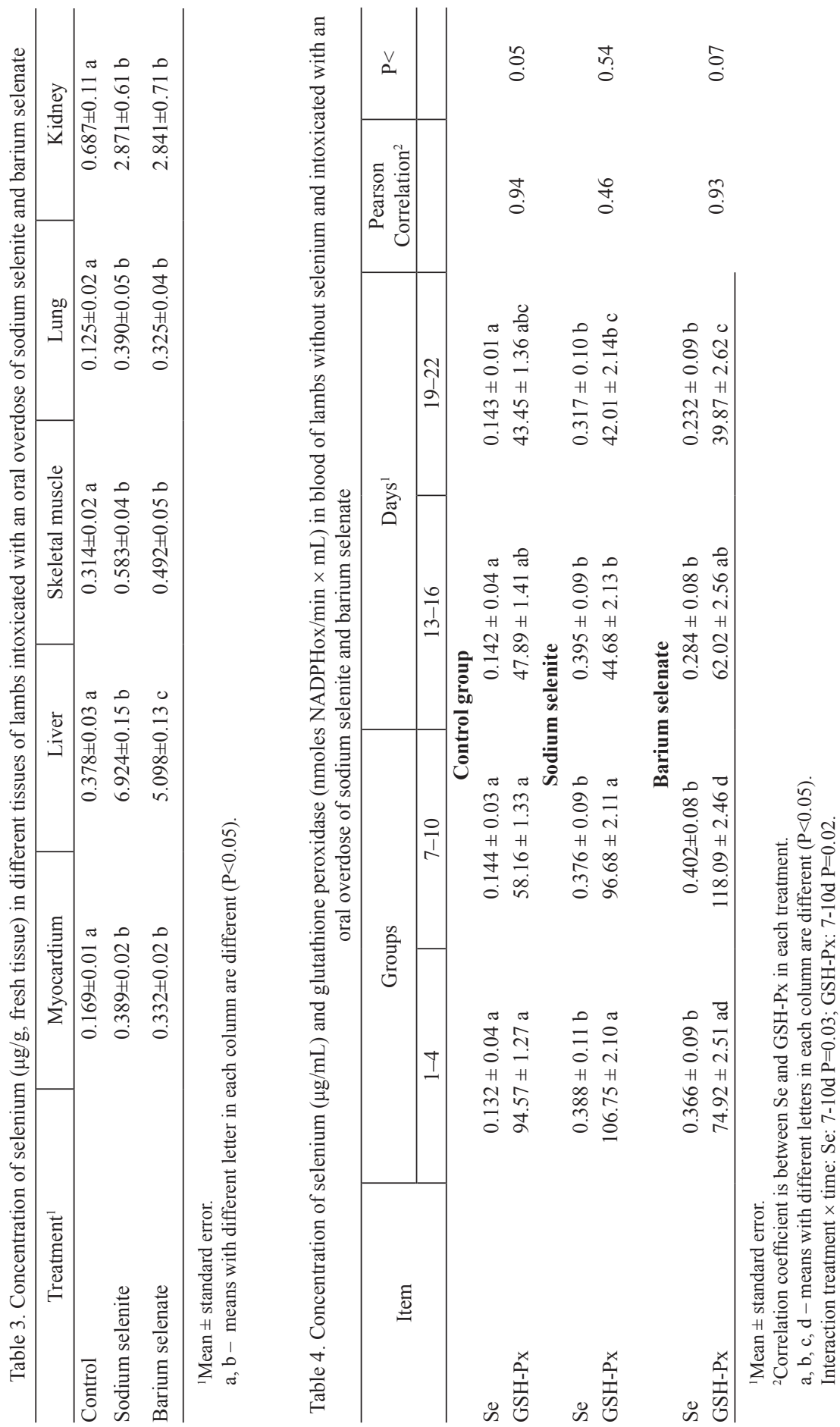


\section{Se and GSH-Px activity in blood}

The Se concentration in blood increased over 2.5 times in the intoxicated lambs with both sources of Se, from baseline to the 22 days of sampling (Table $4, \mathrm{P}<0.05$ ). However, the activity of GSH-Px in lambs intoxicated with both sources of Se decreased after 13 days post intoxication with $\mathrm{SS}(\mathrm{P}<0.05)$. Treatment $\times$ time interactions were observed $(\mathrm{P}<0.03)$ and therefore data were analysed and presented at each treatment and group in days. Se and GSH-Px concentrations from SS were lower $(\mathrm{P}<0.03)$ than those of BS at 7-10 days of sampling (Table 4). There was a lower correlation $(\mathrm{r}=0.46)$ in $\mathrm{SS}$ intoxication group than the control and $\mathrm{BS}$ groups $(\mathrm{r} \geq 0.93)$.

\section{Discussion}

\section{Clinical signs, macroscopic and microscopic findings}

Se tolerance by domestic livestock varies with chemical form of the ingested element, duration and continuity of intake, criterion of tolerance that is applied, and nature of the whole diet (McDowell et al., 2005). Previous NRC publication stated $5.0 \mathrm{mg} \mathrm{Se} / \mathrm{kg} \mathrm{DM}$ of the diet is the maximum tolerable level for small ruminants (NRC, 2007). In contrast to this report, Cristaldi et al. (2005) and Davis et al. (2006) stated that the dose from 10 to $20 \mathrm{mg} \mathrm{Se} / \mathrm{kg}$ DM administered as SS is not toxic to wether lambs and ewes when fed for 12 and 18 months, respectively.

Davis et al. (2006) used ewes weighing $57.4 \mathrm{~kg}$, fed with $1 \mathrm{~kg}$ feed per day on average, adding $20 \mathrm{mg} \mathrm{Se} / \mathrm{kg}$ diet; this is equivalent to $0.35 \mathrm{mg} \mathrm{Se} / \mathrm{kg} \mathrm{BW}$ and did not cause toxicity. On the other hand, Tiwary et al. (2006) reported that doses of $1 \mathrm{mg} \mathrm{Se} / \mathrm{kg} \mathrm{BW}$ (administered daily for 7 days, oral ingestion) did not cause toxicity in lambs, but doses of 2 or $4 \mathrm{mg} \mathrm{Se} / \mathrm{kg} \mathrm{BW}$ (also for 7 days via oral ingestion) as SS or selenomethionine, respectively, caused clinical signs of intoxication as a reduction in feed intake, loss of growth, tetanic spasms, depression, reluctance to move and tachypnea. In our study the accidental and immediate disintegration of intraruminal bolus in the digestive tract caused an immediate decrease in food intake by $66.5 \%$ at 21 days. The bolus released a single dose of $366 \mathrm{mg}$ in the rumen, this concentration was equivalent to $12 \mathrm{mg} \mathrm{Se} / \mathrm{kg} \mathrm{BW}$. Similarly, Tiwary et al. (2006) administered a cumulative dose of $14 \mathrm{mg} \mathrm{Se} / \mathrm{kg} \mathrm{BW}$ as SS (2 mg Se/kg BW daily by a week). We expected to see high lethality in less than $24 \mathrm{~h}$, but there was only one lamb dead in a short time; the other animals showed resistance, trying to consume food and water, but were euthanized at 21 days because of poor body condition and the marginal physical health.

The deceased animal in this study had severe lesions in the myocardium with pulmonary vascular tissue present. It is difficult to sequence these lesions; perhaps heart failure determined vascular changes in the lung and vice versa. Possibly, the increase in pulmonary blood flow resistance was affected in the right heart region. The metallic smell in all lambs intoxicated, should be due to excessive removal of Se by this air; this induced toxic effects on the primary structures of the lungs (Davis 
et al., 2013). The presence of systemic bleeding in acutely intoxicated animals is a common clinical sign in Se poisoning (Abd Elghany and Tórtora, 2010). Muscle lesions observed in lambs (Table 3) also corresponded to muscular dystrophy by Se deficiency; probably this cause was due to a previous lack of Se the lambs showed before start of the experiment (Ramirez et al., 2001).

Se toxicity in sheep usually manifests itself as a neurological sign (blind staggers), possibly accompanied by nephrosis, hepatic fibrosis and myocardial degeneration (Toole and Raisbeck, 1995). In this study, the liver tissue and renal tubules showed coagulation necrosis and slight congestion, the cause was due to the high intake of Se, causing dissociation of disulfide bonds (El-Sayed et al., 2006) and continuing denaturation of proteins. Tiwary et al. (2006) reported significant histopathologic changes in lambs with Se toxicity including multifocal necrosis of the myocardium and vasculitis in lungs alveolar edema and hemorrhage using $8 \mathrm{mg}$ $\mathrm{Se} / \mathrm{kg}$ DM. Conversely, Cristaldi et al. (2005) and Davis et al. (2006) found no significant lesions in microscopic evaluation of tissues using concentrations up to $10 \mathrm{mg} \mathrm{Se} / \mathrm{kg} \mathrm{DM}$; those researchers suggested the possibility of the replacement of Se by sulphur, because of its similar chemical properties, reactions and important biochemical structures such as disulphide bonds by altering the protein conformation, including enzymes, which seriously affects the cell function. There are alterations in skin lesions considering the abundance of disulphide bonds in keratin. Another possibility that has been specially considered is that the free radicals and superoxide anions can react with the Se and lead to tissue damage (Hoffman, 2002). None of the above proposals can explain all components of intoxication. Similarly, Tiwary et al. (2006) reported histopathological changes as acute multifocal myocardial necrosis with scarce lymphocytic interstitial, pulmonary vasculitis with alveolar haemorrhage and edema and mild hepatic congestion.

\section{Se concentration in tissues}

Se available to the ruminants is either organic or inorganic form; the recent research that has been performed indicates that organic Se is slightly better absorbed than inorganic Se (Koenig and Beauchemin, 2009), but its disadvantage is the high cost and its use may be more justified in dairy animals or breeding. The lambs to be fattened for meat production can be given organic Se supplementation through ingredient diets and sources of inorganic Se salts to cover the requirement. Thus, $\mathrm{Se}$ is found in all tissues in concentrations that vary with the source administered by rumen and the type of tissue. In the study reported here, lambs who were not supplemented with Se had higher concentration of it in the kidneys than the liver. Tiwary et al. (2006) reported that the administration of Se as SS at doses of $4 \mathrm{mg} / \mathrm{kg} \mathrm{BW}$ (this amount equals $\sim 133 \mathrm{mg} / \mathrm{Kg}$ Se on ration DM basis), significantly increased the accumulation of Se in liver (6.7), kidney cortex (2.5) and heart (0.474 $\mu \mathrm{g} / \mathrm{g}$ Se wet weight). Davis et al. (2008) also administering SS and organic Se (20 mg Se/kg DM) in lambs reported high concentration in liver, and subsequently in kidney, heart, spleen, brain, diaphragm, and heart tissue showed a range from 1.59 to $33.93 \mu \mathrm{g} / \mathrm{g}$ Se. No information was published on toxicities induced with BS, the accumulation in this group was lower than the group intoxicated with SS. Published 
literature mentions that Se is more efficiently absorbed as selenate than as selenite, and selenite form is more readily reduced to less available elemental Se which may form insoluble compounds with others metals (McDowell et al., 2002). From these findings it can be inferred that the accumulation of Se toxicity occurs first in the liver, and the Se is excreted in urine, feces and expired in air; however, urinary excretion of these homeostatic processes is considered the primary route (Ganther, 1986; Ohta et al., 2009) and in sequence, kidney injuries were caused by the high amounts of Se in the urine due to more accumulation of selenoenzymes in the kidneys (Voudouri et al., 2003).

\section{Se and GSH-Px activity in blood}

Published data on the activity of GSH-Px, as an indirect method to measure the concentration of Se is not clear. Gerloff (1992) reported the activity of GSH-Px can be an indicator of long-term supplementation of organism with Se, while determination of blood Se content indicates the short-term variation in the concentration of this microelement; however, the regression coefficients are variable and range from 0.4 to 0.9 (Ceballos et al., 1999; Gunter et al., 2003). In general, the response of the GSH-Px depends on the status of Se in the animal organism, physiological state and species. In this study, the correlation of Se and GSH-Px showed a high association $(r \geq 0.93)$ in the group intoxicated with BS (similar to control group). The animals of this group showed a constant excess of Se in the blood and liver, accumulating lower Se than the group intoxicated with SS. Most of the literature reported findings of SS and selenomethionine toxicity, but no published studies referring to a high dose of BS. Only McDowell et al. (2002) reported that BS was more effective in elevating calf blood than SS.

As a conclusion, the chemical form of Se ingested is influenced by the accumulation in tissues. Animals receiving excessive doses of Se accumulated more Se in kidney, muscle, liver and lung. The enzymatic activity of GSH-Px and Se sources was different; BS dosage showed more correlation between Se blood and GSH-Px activity than SS. High dosages of $366 \mathrm{mg} \mathrm{Se}(12 \mathrm{mg} \mathrm{Se} / \mathrm{kg} \mathrm{BW})$ in an accidental shot did not cause severe mortality but all lambs immediately showed reduced feed intake, metallic smell exhalation and depression.

\section{References}

A bd Elgh any H., Tórtor a P.J. (2010). The importance of selenium and the effects of its deficiency in animal health. Small Rumin. Res., 89: 185-192.

A bd Elghany H., Revilla V.A., López A.R., Ramírez B.E., Tórtora P.J. (2007). The relationship between fetal and maternal selenium concentrations in sheep and goats. Small Rumin. Res., 73: 174-180.

Behne D., Kyriakopoulos A.S. (2001). Mammalian selenium containing proteins. An. Rev. Nutr., 21: 453-473.

Ceballos A.F., Wittwer G., Contreras P.A., Quiroz E., Böhmwald H.L. (1999). Blood activity of glutathione peroxidase and its correlation with blood selenium concentration in grazing dairy cattle. Pes. Agrop. Bras., 34: 2331-2338. 
Crist a $1 \mathrm{~d}$ i L.A., Mc Dow e 11 L.R., B u e rge $1 \mathrm{t}$ C.D., D a v is P.A., Wi 1 kin son N.S., Mart in F.G. (2005). Tolerance of inorganic selenium in wether sheep. Small Rumin. Res., 56: 205-213.

Davis P.A., Mc Dow e 11 L.R., Wilkins on N.S., Buergelt C.D., Van Als tyne R., We 1 d on R.N., Marshall T.T. (2006). Tolerance of organic selenium by range-type ewes during gestation and lactation. J. Anim. Sci., 84: 660-668.

Davis P.A., Mc Dow e 11 L.R., Wilk ins on N.S., B u e rge 1 t C.D., Van Als ty ne R., We 1 don R.N., Marshall T.T., Mats u d a - F u g is a ki E.Y. (2008). Comparative effects of various dietary levels of Se as sodium selenite or Se yeast on blood, wool, and tissue Se concentrations of wether sheep. Small Rumin. Res., 74: 149-158.

D a v i s T.Z., S t e g e $1 \mathrm{~m}$ e i e r B.L., Gre e n B.T., We $1 \mathrm{c}$ h K.D., H a 11 J.O. (2013). Evaluation of the respiratory elimination kinetics of selenite and Se-methylselenocysteine after oral administration in lambs. Res. Vet. Sci., 95: 1163-1168.

E 1 - S a y e d W.M., A b o u 1 - F a d 1 T., L a m b J.G., R obert s J.C., Franklin M.R. (2006). Effect of selenium-containing compounds on hepatic chemoprotective enzymes in mice. Toxicol., 220: $179-188$.

FDA (2004). Title 21. Food and drugs: Food additives permitted in feed and drinking water of animals. http://www.accessdata.fda.gov/scripts/cdrh/cfdocs/cfcfr/CFRSearch.cfm?fr=573.685 (consulted in January 2014).

Ganther H.E. (1986). Pathways of selenium metabolism including respiratory excretory products. Int. J. Toxicol., 5: 1-5.

Gerloff B.L. (1992). Effect of selenium supplementation on dairy cattle. J. Anim. Sci., 70: 3934-3940.

Gunter S.A., B eck P.A., Phillips J.M. (2003). Effects of supplementary selenium source on the performance of blood measurements in beef cows and their calves. J. Anim. Sci., 81: $856-864$.

Gurvan M., Helbert W., Kahn R., Dideberg O., Kl oareg B. (2003). The structural bases of the progressive degradation of I-carrageenan, a main cell wall polysaccharide of red algae. J. Mol. Biol., 334: 421-433.

Gutierrez O.C., Spross S.A., Rosiles M.R., Ducoing W.A., Ortiz H.A. (2005). Se sanguíneo y fecal en ovinos a partir de comprimidos inorgánicos intrarruminales. Vet. Méx., 36: $313-324$.

$\mathrm{H}$ o ff $\mathrm{m}$ a $\mathrm{n}$ D.J. (2002). Role of selenium toxicity and oxidative stress in aquatic birds. Aquatic Toxicol., 57: 11-26.

J u d s o n G.H. (1991). Long-acting selenium treatment for sheep. Aust. Vet. J., G8: 263-265.

K o e n i g K.M., B e a u c h e min K.A. (2009). Supplementing selenium yeast to diets with adequate concentrations of selenium: Selenium status, thyroid hormone concentrations and passive transfer of immunoglobulins in dairy cows and calves. Can. J. Anim. Sci., 89: 111-122.

Kuttler K.L., Marble D.W., B lin c o e C. (1961). Serum and tissue residues following selenium injections in sheep. Am. J. Vet. Res., 22: 422-424.

McDowell L.R., Valle G., Cristaldi L., Davis P.A., Ros endo O., Wilkinson N.S. (2002). Selenium availability and methods of selenium supplementation for grazing animals. Proceedings 13th Annual Florida Ruminant Nutrition Symposium, pp. 86-102.

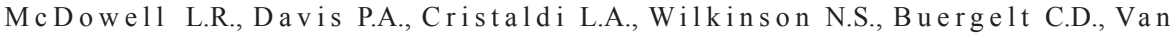
A 1 s t y ne R. (2005). Selenium toxicity for ruminants - Paranoia or precaution?. Florida Ruminant Nutrition Symposium. University of Florida USA, p. 38-49.

O h t a Y., K o b a y a s h i Y., K on is hi S. (2009). Speciation analysis of selenium metabolites in urine and breath by HPLC- and GC-inductively coupled plasma-MS after administration of selenomethionine and methylselenocysteine to rats. Chem. Res. Toxicol., 22: 1795-1801.

P a g l i a D.E., Valentin e W.N. (1967). Studies on the quantitative and qualitative characterization of erythrocyte glutathione peroxidase. J. Lab. Clinic. Med., 70: 158-169.

R a mír ez B.J.E., Tór tor a P.J.L., Hernán de z L.M., H u e rt a M. (2001). Main causes of mortalities in dairy goat kids from the Mexican plateau. Small Rumin. Res., 41: 77-80.

Tiw a ry K.A., S t e g e $1 \mathrm{~m}$ e i e r B.L., P a n t e r K.E., J a m e L.F., H a 11 J.O. (2006). Comparative toxicosis of sodium selenite and selenomethionine in lambs. J. Vet. Diag. Inv., 18: 61-70. 
To ole D.O., R a is b e c k M.F. (1995). Pathology of experimentally induced chronic selenosis (alkali disease) in yearling cattle. J. Vet. Diag. Inv., 7: 364-373.

Voudouri A.E., Chadio S.E., Menegatos J.G., Zrvas G.P., Nicol F., Arthur J.R. (2003). Selenoenzyme activities in selenium and iodine deficient sheep. Biol. Trace Elemen. Res., 94: 213-224.

Received: 30 VI 2014

Accepted: 15 I 2015 